\title{
INDUCED MUTATION ON JATROPHA (Jatropha curcas L.) FOR IMPROVEMENT OF AGRONOMIC CHARACTERS VARIABILITY
}

\author{
Ita Dwimahyani and Ishak \\ Centre for Research and Development of Isotopes and Radiation Technique \\ National Nuclear Energy Agency, Jakarta, Indonesia
}

\begin{abstract}
ABTRACT
INDUCED MUTATION ON JATROPHA (Jatropha curcas L) FOR IMPROVEMENT OF AGRONOMIC CHARACTERS VARIABILITY. Induced mutation can be used for improving quality in term of seed production, oil content in seed and early maturity of Jatropha with the aim for bio_diesel in Indonesia. The doses of 10, 15,20, and $25 \mathrm{~Gy}$ of gamma applied to cuttings was able to increase genetic variability in vegetatively propagated plants of Jatropha at M1V1 (mutant-1 vegetative-1) generation. Selection for desirable trait will be done at M1 V2 (mutant-1 and vegetative-2) generation untill homogenous plants obtained. Gamma rays at dose of 20 to 25 Gy damaged several genes controlling growth and development on Jatropha which was shown by dwarf and poor plant growth compared to control (plant without irradiation). Irradiation with the dose of $10 \mathrm{~Gy}$ raised genetic variability on plant development which was identified with early maturity, 100 seeds weight was $30 \%$ over control, and the number of branch growth was good.
\end{abstract}

Key words: Jatropha curcas, mutation breeding, genetic variability, bio-dieseloil.

\section{INTRODUCTION}

Jatropha (Jatropha curcas L.) known as purging-nut, is a large shrub or small tree originated from tropical America, but commonly found and utilized throughout most of the tropical and subtropical regions of the world [1]. It is still uncertain where the centre of origin is, but it is believed to be Mexico and Central America. It was introduced to Africa and Asia and is now cultivated world wide, especially in dry land. Jatropha is resistant to drought and can be planted even in the desert climates; and it thrives on any type of soil; in sandy, gravelly and saline soils [2]. In Indonesia (Java island), people grow Jatropha as fence along the side of road or as border perimeter plant, so it is called Jarak Pagar which mean fence of Jatropha [3].

Traditionally, the cultivation of Jatropha has been undertaken primarily for protection of crops or pasture land by serving as a fence to confine livestock or as hedge for erosion control or as wind break. The ability of Jatropha to establish and be productive across a wide range of growing conditions, even on sites with poor quality soils and long period of drought, makes it a desirable species for degraded lands and preventing erosion. In equatorial regions, in which moisture is not a limiting factor, Jatropha is able to bloom and produce fruits around the year [4].

The oil content of Jatropha seed ranges from 35 - 58 percent by weight, and those of the kernel ranges from 40 - 60 percent $[5,6,7,8]$. Research on this oil for diesel was first initiated during the Second World War, to study its 
use as a liquid, clean air and renewable fuel substitute for diesel oil $[9,10,11,12]$. As a crop, Jatropha represents a renewable resource of energy for the high content of oil yield.(8). By simple technology, traditional people have used Jatropha for their life as lamp oil, medicine, insecticide, soap and wax. The Jatropha oil for bio-diesel have been used in India, Mesir, Brasil and a lot of countries in Afrika like Mali, Zimbabwe, Belize, Tanzania, Ghana. A number of researches have shown that Jatropha bio-diesel has fuel properties and provides very similar engine performance to diesel fuel (Table. 1)

Table 1. The comparison of Jatropha oil to Diesel fuel.

\begin{tabular}{|c|c|c|}
\hline Parameter & Diesel fuel & Jatropha oil \\
\hline Energy content $(\mathrm{MJ} / \mathrm{kg})$ & $42.6-45.0$ & $39.6-41.8$ \\
\hline Viscosity $(\mathrm{cp})\left(30^{\circ} \mathrm{C}\right)$ & 3.60 & 52.6 \\
\hline Specific gravity $\left(15 / 4^{\circ} \mathrm{C}\right)$ & $0.84-0.85$ & $0.91-0.92$ \\
\hline Solidifying point $\left({ }^{\circ} \mathrm{C}\right)$ & -14.0 & 2.0 \\
\hline Flash point $\left({ }^{\circ} \mathrm{C}\right)$ & 80 & $110-240$ \\
\hline Cetane value & 47.8 & 51.0 \\
\hline Sulphur $(\%)$ & $1.0-1.2$ & 0.13 \\
\hline
\end{tabular}

Source:Use of Jatropha available from http://www.jatropha.de/use-of-oil.htm (8)

Jatropha oil hold the promise of alternative fuel for diesel engine, because of its potential in substituting the depleting primary fuels, its agriculture oriented, reduces serious air pollutant (such as particulates, carbon monoxides, hydrocarbons and air toxic), non toxic, bio degradable and renewable fuel. It is important to consider the use of mutation breeding for the improvement of Jatropha as a fuel crop, in term of its production and oil content in the seeds. Untill now, there is no report about Jatropha commercial cultivation.

Propagation of Jatropha vegetativelly is not difficult, therefore, improving agronomic characters of this plant genetically using nuclear technique will give advantage in obtaining superior allele based on mutation process. Mutation breeding relied on physical mutagen or chemical mutagen in order to occur mutation in genes or chromosomes level. Mutation in plant cell can produce genetic variance in gene or chromosomes level, and the change over the gene can be shown in the phenotypic appearance. This genetic variance is used as selection purposes with desirable traits in subsequent generation.

The use of physical mutagen such as gamma irradiation is commonly used for mutation purposes. Gamma irradiation derived from cobalt sources can hit cell target directly in the nucleous of cell. Mutation takes place randomly in gene or chromosomes, it is then occurring recombinant from original DNA structures. There are two possibilities taking place during mutation process in gene level: (1) gene mutation occurred in positive 
manner i.e. desirable trait obtained through mutation process, and (2) gene mutation taking place in negative direction, i.e. mutant obtained with negative traits such as albino plants or plant which sensitive to disease. Therefore, an appropriate selection method becomes a key point in obtaining desirable trait during selection process.

The objective of this work are divided into two categories of experiment. The first is to increase genetic variance of Jatropha using gamma rays, to obtain superior allele in term of seed production. The second is to analyse oil content and quality in seed of Jatropha produced by the lines.

\section{MATERIALS AND METHOD}

\section{Plant preparation}

Plant materials were collected from different places around Jakarta, which were selected plants with a lot of branches and seeds. Branches derived form a single plant were then cut into $30 \mathrm{~cm}$ length, before being irradiated.

\section{Gamma Irradiation}

Ten cuttings were irradiated using gamma rays, with the doses of 10, 15, 20, 25 and $30 \mathrm{~Gy}$. After irradiation, each cutting was planted in polybag $5 \mathrm{~kg}$ size, with soil.

\section{Soil preparation}

Soil was taken from cultivated area at Pasar Jumat, Jakarta Selatan, then dried for three days and mixed with farm manure with the ratio of 2:1. The mixed soil were put into the polybags till $3 / 4$ part.

Steps of the research activity were as follow:

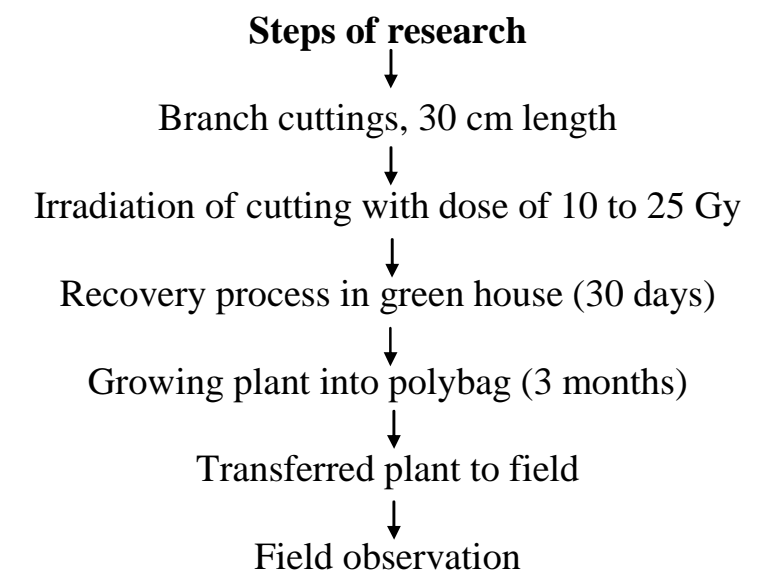




\section{RESULTS AND DISCUSSION}

The effects of gamma rays on the growth performance of Jatropha can be seen in Fig.1. Dose of 20 Gy gave rise abnormality in the plant appearance i.e. dwarf. Such dose also reduced survival rate of the plant to $40 \%$. Branch length of the plant derived from irradiated cuttings only reaches $2,79 \mathrm{~cm}$ compared to the control plant which was $8.64 \mathrm{~cm}$ (Table 2). Short branch and dwarf Jatropha plant will influence plant productivities, and from economical point of view do not give any benefit.

The cutting treated with the dose of 10 to 15 Gy showed higher survival rate $70 \%$ and normal plant performance. Ganesan et al. [13] created genetic variability in seed of Ricinnus communis L by using gamma rays with the dose of $300 \mathrm{~Gy}$. and increased its seed production over $30 \%$. Higher dose of gamma rays was applied to the seed, because of its lower water content. Our experiment on irradiation of Jatropha cutting showed that dose of gamma rays started from $10 \mathrm{~Gy}$ created genetic variability of plant growth

There are several strategy to improve agronomic characters of Jatropha such as cross breeding, mutation breeding, and genetic engineering. Choosing mutation breeding to improve agronomic characters of Jatropha, we regarded that mutation breeding is more efficient and cheaper when compared to the use other methods. Cross breeding method will take several years in order to establish homozygot plant. While genetic engineering method for Jatropha has not established yet [14]

Several agronomic characters of irradiated Jatropha cutting, such as plant height, number of fruit per branch, and 100 seeds weight were observed in the field. The results showed that gamma irradiation with the dose of 10 Gy stimulated plant growth and increased seed weight $20 \%$ over control (Table 3.). Low dose of gamma rays was applied on cutting of Jatropha compared to seeds, because cutting was more sensitive to gamma irradiation. Growth performance and the agronomic characters of Jatropha plant derived from irradiated cuttings was shown in Table 2 and 3.

Vegetatively propagated plants of Jatropha were not difficult to grow in the field and the seeds could be harvest within 3.5 to 4.5 month (Table 4). Flowering stage in mutant lines was 57 days and one month later produced seed (Fig. 4). The first seed harvest of the mutant lines was done at the age of 99 days, while that of the control at the age of 157 days. The maturity of plant control was earlier compared to another genotipe from another countris $[2,15]$. Results experiments showed that flowering stages started from 50 days to 62 days indicated by $50 \%$ of total plants has showed flower. 
Table 2. Growth performance of Jatropha plants derived from cuttings irradiated with different dose of gamma (30 days)

\begin{tabular}{|c|c|c|c|c|}
\hline $\begin{array}{c}\text { Dose of } y \text { rays } \\
(\mathrm{Gy})\end{array}$ & $\begin{array}{c}\text { Survival rate } \\
(\%)\end{array}$ & $\begin{array}{c}\text { Number of } \\
\text { leave }\end{array}$ & $\begin{array}{c}\text { Branch length } \\
(\mathrm{cm})\end{array}$ & Abnormality \\
\hline Untreated & 80 & 52,8 & 8,64 & None \\
\hline 10 & 70 & 24,6 & 5,64 & None \\
\hline 15 & 70 & 21,6 & 5,07 & None \\
\hline 20 & 40 & 9,8 & 2,79 & Dwarf \\
\hline 25 & 10 & - & 0,43 & Dwarf stunted \\
\hline
\end{tabular}

Table 3. The agronomic characters of M1V1 (mutant-1, vegetative-1) generation of Jatropha (150 days)

\begin{tabular}{|c|c|c|c|c|}
\hline $\begin{array}{c}\text { Dose of } y \text { rays } \\
(\mathrm{Gy})\end{array}$ & $\begin{array}{c}\text { Plant height } \\
(\mathrm{cm})\end{array}$ & $\begin{array}{c}\text { Number of } \\
\text { branch }\end{array}$ & $\begin{array}{c}\text { Number of fruit } \\
\text { per branch }\end{array}$ & $\begin{array}{c}\text { Weight } 100 \\
\text { seed }(\mathrm{g})\end{array}$ \\
\hline 0 (Untreated) & $64,33 \pm 11,79$ & $3,86 \pm 1,35$ & $8,00 \pm 4,00$ & $52,40 \pm 8,90$ \\
\hline 10 & $68,00 \pm 10,52$ & $3,00 \pm 0,58$ & $9,09 \pm 3,80$ & $62,70 \pm 8,20$ \\
\hline 15 & $59,33 \pm 3,39$ & $2,80 \pm 0,84$ & $7,33 \pm 3,08$ & $55,40 \pm 8,90$ \\
\hline 20 & $46,50 \pm 9,95$ & $2,67 \pm 0,84$ & $5,00 \pm 0,82$ & $41,80 \pm 12,00$ \\
\hline 25 & - & - & - & - \\
\hline
\end{tabular}

Table 4. The observation of the age of flowering stage to bear stages

\begin{tabular}{|c|c|c|c|}
\hline \multirow{2}{*}{ Genotype } & \multicolumn{3}{|c|}{ Observation of the age of flowering stages to bear fruit } \\
\cline { 2 - 4 } & $\begin{array}{c}\text { The age of flowering } \\
50 \% \text { (days) }\end{array}$ & $\begin{array}{c}\text { Bear fruit 50\% } \\
\text { (days) }\end{array}$ & $\begin{array}{c}\text { Harvested 50\% } \\
\text { (days) }\end{array}$ \\
\hline J0-04( control) & 93 & 120 & 157 \\
\hline J10-04 & 57 & 77 & 99 \\
\hline J15-04 & 72 & 103 & 132 \\
\hline J20-04 & 105 & 135 & 167 \\
\hline J25-04 & - & - & - \\
\hline
\end{tabular}

Notes: $\mathrm{Jx}_{\mathrm{ij}}-04 ; \mathrm{J}=\mathrm{Jatropha} ; \mathrm{x}_{\mathrm{ij}}=$ irradiation dose from $\mathrm{i}$ to $\mathrm{j} ; 04=$ the year of experiment 


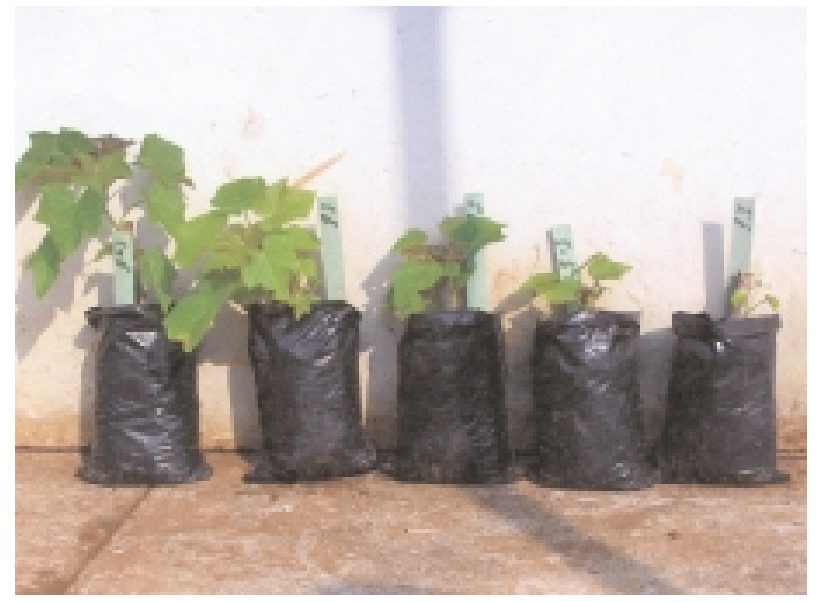

Figure 1. Growth Performance of Plant Derived from Jatropha Cuttings Irradiated with Different Doses of Gamma. From left to right: 0 (control), 10, 15, 20 and 25 Gy respectively.
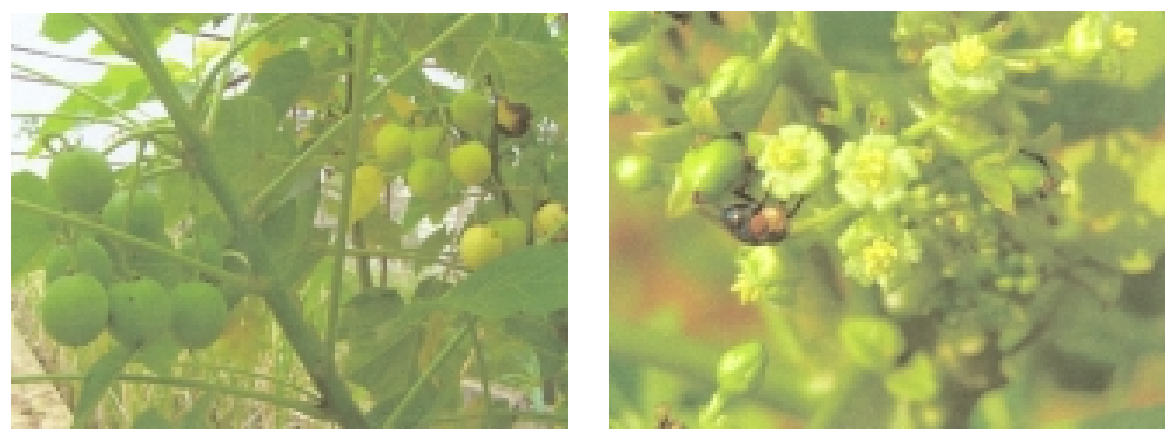

Figure 2. Fruis and flower of Jatropha curcas.

\section{CONCLUSION}

Experiment results showed that gamma irradiation on cutting of Jatropha curcas with the dose of $10 \mathrm{~Gy}$ created genetic variability which was showed by earlier maturity on $\mathrm{J} 10-04$ genotype and by the increased of 100 seeds weight. Appropriate irradiation dose to treat cuttings of Jatropha was ranging from 10 to $15 \mathrm{~Gy}$. J10-04 mutant lines will be observed further on the oil content in the seed and to confirm that the chimera plant in cells population be eliminated. 


\section{REFERENCES}

1. Tropicalab, "Jatropha curcas-physic nut" (2004). http//www. tropilab.com/jatropha-cur-html

2. DORTHE JOKER DFSC and JACOB JEPSEN, Seed Leaflet, Jatropha curcas L, Danida Forrest Seed Centre, Denmark, no:83. (2003). available from $\mathrm{http} / \mathrm{www}$.disc.dk.

3. HEYNE, K., The Beneficial Plant of Indonesia, Translated by Forrest Research and Development Agency, Jakarta. P: 1180-1182 (1987).

4. Anonymous, Using the indigenous knowledge of Jatropha, World Bank, No .47:1-4(2002).

5. HENNING, R.K., "Fighting Desertification by integrated utilization of Jatropha plant", http//www. Jatropha.org.

6. REYADH, M, The Cultivation of Jatropha curcas in Egypt (2004). http//www. Jatropha

7. Anonymous, Word Agroforestry Center, Agroforestry Database, (2004). (2004).http//www.worldagroforestry.

8. DUKE, J,A, Jatropha curcas L. (1998). available from http//www. hort.purdue.edu/newcrop/duke-energy/jatropha curcas html).

9. DUKE, J.A, Jatropha curcas L. Handbook of Energy Crops, unpublished (1983).

10. GRIFFITH, M., The application of biotechnology to Industrial sustainability, OECD, Paris, Available from http//www.oecd.org., Paris (2001).

11. Anonymous, Energy corner-non wood news, FAO, No.2 (2004), available from $\mathrm{http} / / \mathrm{www}$.fao-org/doc.rep.

12. KRYL, D. Environmental and Industrial biotechnology in developing country, electrical journal of biotechnology pp: 1-5 (2001).

13. GANESAN, K. HUSSAIN, HS, and VINDHIYAVARMAN, $\mathrm{P}$, "Induced mutation in Castor" Mutation Breeding News Letter No.45 :20 (2001). 
14. ITA DWIMAHYANI and ISHAK, Mutation Breeding and Biotechnology on Jatropha (Jatropha curcas L) for biodiesel future energy. Presented on Seminar Mutation Breeding in Forum Nuclear Cooperation in Asia, 30 August-3 September 2004, Jogyakarta, Indonesia (2004).

15. JONES, N. and MILLER, JH, Jatropha Curcas: A Multipurpose Species For Problematic Sites, World Bank, Asia Technical Department, Agriculture Division. (1998). 